\title{
Evaluation of Different Litter Materials for Broiler Production
}

\author{
A.P.S. Dhaliwal, Balwinder Singh Dhillon* and J.S. Brar \\ Krishi Vigyan Kendra, Bathinda-151 001, Punjab, India \\ *Corresponding author
}

\begin{tabular}{|l|}
\hline Ke y w o r d s \\
$\begin{array}{l}\text { Broiler birds, Feed } \\
\text { conversion ratio, } \\
\text { Litter materials, } \\
\text { Moisture content }\end{array}$ \\
\hline Article Info \\
\hline $\begin{array}{l}\text { Accepted: } \\
10 \text { November } 2018 \\
\text { Available Online: } \\
10 \text { December } 2018\end{array}$ \\
\hline
\end{tabular}

A B S T R A C T

The aim of this study was to determine the selection of bedding material used in broiler birds during the rearing period. Total 72 broiler chicks of IBL- 80 were used on a completely randomized design in four treatments of deep litter materials i.e. wheat straw, rice husk, mustard stalk and sand. This study includes four treatments along with three replicates and each replicate consists of 18 birds. Standard feeding and management practices were followed during the experimental period. Differences in average weight gain, feed consumption, feed conversion ratio (FCR) and dressing percentage of wheat straw, rice husk, mustard stalk were significantly higher than sand, while, mortality was higher in sand treatment. The moisture content increased from 8.15 to $40.4 \%$ in wheat straw, 11.4 to $45.3 \%$ in rice husk, 7.80 to $38.7 \%$ in mustard stalk and 2.2 to $17.4 \%$ in sand during the study. The cost of litter for rearing one bird in deep litter system was Rs. 1.74, $1.53,1.45$ and 1.68 for sand, mustard stalk, rice straw and wheat straw respectively. It was concluded that any of these three bedding materials (wheat straw, rice husk and mustard stalk) may be used and these are cheap and locally available to the poultry entrepreneurs. Overall rice husk gives excellent results as they have the ability to absorb the moisture and remain dry which is the basic requirement of deep litter system. The manure quality of rice husk is very excellent as compare to other materials.

\section{Introduction}

Poultry is the most organised sector in animal production system. The growth is $6-8 \%$ in layers and $10-12 \%$ in broilers per year against the growth of agriculture as a whole which is around $2.5 \%$. Within a span of 25 years, the egg production has gone up to 70 billion from few millions and the broiler production has gone to 3.8 million tonne from nowhere. India is the third-largest egg producer after China and USA and the fourth-largest chicken producer after China, Brazil and USA. The per capita eggs consumption has gone up from 30 to 68 and the chicken from $400 \mathrm{gm}$ to $2.5 \mathrm{~kg}$.

To obtain maximum meat production, management in the poultry house is very essential. One of the management practices is the proper maintenance of poultry litter commonly named as deep litter system of management. The litter material is used in a poultry farm to give more comfort to the birds 
for best profitable outcomes. The quality of litter material significantly influences the overall performances of the broilers as well as the chickens. A good litter serves as an insulator to maintain uniform temperature round the year and also acts as a blotter through absorbing the extra moisture of the feces and urine by increasing surface area of the floor which prevents fungal contamination. The quality of litter significantly influences the overall performance and ultimately the profit. Litter plays a vital role in absorbing the fecal moisture, promotes drying by increasing surface area of the house floor, insulates chick from cooling effects of the ground and provide a protected cushion. Litter material helps to conserve heat by insulation and provide supplemental heat through fermentation by feacal microorganisms. It receives droppings and absorbs moisture from faeces and respiratory processes. It provides a warm, soft and spongy surface for optimum comfort of the birds.

A variety of litter material including paper products (Lien et al., 1992), gypsum (Grimes et al., 2007), hardwood bark (Brake et al., 1992), sand (Shields et al., 2005), rice and wheat straw (Sreehari and Sharma 2010), ground corn cob and soybean straw (De Avila et al., 2008) have been used as substitute bedding materials with various level of success. Particle size, absence of dust, bulk density, thermal conductivity, drying rate and compressibility make pine shavings an ideal bedding material for broilers and layer birds. Therefore, the first aim of the present research was to assess the selection by rearing egg laying birds in different types of materials widely used as litter in the poultry industry (wheat straw, rice husk, mustard stalk (Phulk) and sand). The second objective of this study was to determine the predominant behaviours on each of these materials. Moreover, the characteristics of the materials used as broiler substrate must be taken into account, because some substrates may enrich the environment and support important behaviours of the birds (Gunnarson et al., 2000), as well as determine chickens' skin condition (Mendes et al., 2011). Thus, providing a good litter would be an effective way to increase broiler activity (Shields et al., 2005) and to reduce locomotion problems (Almeida Paz et al., 2010).

\section{Materials and Methods}

\section{Experiment details}

The experiment was conducted at Poultry Unit of Krishi Vigyan Kendra (KVK), Bathinda (Punjab, INDIA). Four $(12 \mathrm{~m} \times 10 \mathrm{~m})$ broiler houses were internally divided in four pens each. For the present study day old chicks of IBL-80 procured from GADVASU, Ludhiana were reared. There were four treatments of litter material i.e. wheat straw, rice husk, mustard stalk (Phulk) and sand and each treatment was then replicated three times of 18 chicks each in Completely Randomized Design (CRD). The chicks were routinely vaccinated and reared under strict hygienic conditions maintaining all standard managemental practices including brooding, proper lighting, raking of litter, cleaning of feeders and drinkers etc. The birds belonging to all the experimental groups were closely observed throughout the experiment, starting from day old till the end of experiment i.e. 56 days ( 8 weeks) of rearing birds.

\section{Data recording}

The gain in body weight for each bird was recorded on weekly basis by subtracting the initial body weight from the weight recorded at the seventh day of each week. The feed and water was offered ad libitum and the leftover feed was recorded at next morning. Feed consumption was calculated for each group by subtracting the leftover feed from the feed 
offered. The feed conversion ratio (FCR) for each replicate on weekly basis was calculated by dividing the mean weekly total quantity of feed consumed by the mean weekly total gain in body weight. At the end of the experiment, the birds were kept fasting for 5-6 hours and no feed was offered during this withdrawal period to keep the crop of the bird empty at slaughtering time. Three birds were randomly selected from each replicate, weighed and immediately slaughtered. After removing feathers along with the skin, head, legs and all internal organs including heart, gizzard, liver and abdominal fat, the carcass was weighed to determine dressing percentage. Mortality was recorded daily. The dead birds were dissected to determine the causes of death. Samples of litter were taken in plastic bags from each replicate on weekly basis to determine the amount of moisture. Water absorbing or holding capacity was determined according to procedure described by Davasgaium and Boodoo (2000). Economics of each litter material was calculated according to prevailing market prices at the time of the trial.

\section{Data analysis}

The data were statistically analyzed with the standard procedures of Analysis of Variance (ANOVA), using Completely Randomized Design, as described by Steel and Torrie (1981). The means were compared for significance of difference with the Duncan's Multiple Range Test for variables. The statistical package (SAS, 2000) was used to perform the above analysis.

\section{Results and Discussion}

\section{Growth performance of birds}

There was no significant difference $(\mathrm{P}<0.05)$ between the rice husk, wheat straw and mustard stalk in average weight gain and feed consumption (Table 1). However, it was found that birds reared on rice husk gained the highest body weight followed by those on mustard stalk and wheat straw. But average weight gain and feed consumption of birds reared in the rice husk, wheat straw and mustard stalk were significantly higher than sand. Feed consumption of the birds reared on different litter materials i.e. rice husk, wheat straw and mustard stalk was more or less similar, although birds on saw consumed the lowest amount of feed. This is in agreement with the findings of Davasgaium and Boodoo (2000).

Feed consumption ratio of birds reared on mustard stalk was significantly higher than sand, but statistically similar with rice husk and wheat straw. Dressing percentage of birds reared on sand was significantly lower than rice husk, wheat straw and mustard stalk. There was no significant difference $(\mathrm{P}<0.05)$ between the rice husk, wheat straw and mustard stalk in dressing percentage. Mortality not differed significantly among rice husk, wheat straw, mustard stalk and sand. However, higher mortality was recorded in sand treatment.

However, the better livability was found on sawdust and rice husk (100\%) which was supported by Hussain et al., (1996) and Kassid and Coleman (1990).

The average recorded temperature and Relative humidity were $29.55^{\circ} \mathrm{C}$ and $78.73 \%$ respectively during experimental period.

\section{Manureal value of different litter materials ( $N, P$ and $K$ content)}

Rice husk contained the highest percentage of moisture followed by wheat straw, mustard stalk and sand (Table 2). The significant difference was found for nitrogen, phosphorus and potassium content among different types of used litter. The maximum values of nitrogen, phosphorus and potassium content 
were recorded in rice husk. Similar results were also found earlier by Monira et al., (2003). In this study used rice husk appeared to be best manure in respect of nitrogen, phosphorus and potassium content.

Table.1 Performance of broilers reared on four types of litters up to 56 days of age

\begin{tabular}{|l|c|c|c|c|}
\hline \multicolumn{1}{|c|}{ Parameters } & \multicolumn{4}{|c|}{ Types of litter } \\
\cline { 2 - 5 } & $\begin{array}{c}\text { Wheat } \\
\text { straw }\end{array}$ & Rice husk & Mustard stalk & Sand \\
\hline $\begin{array}{l}\text { Avg. weight gain } \\
\text { (g/bird) }\end{array}$ & $1608.04^{\mathrm{a}}$ & $1625.03^{\mathrm{a}}$ & $1612.07^{\mathrm{a}}$ & $1602.09^{\mathrm{b}}$ \\
\hline $\begin{array}{l}\text { Feed consumption } \\
\text { (g/bird) }\end{array}$ & $3952.00^{\mathrm{a}}$ & $4066.00^{\mathrm{a}}$ & $3995.00^{\mathrm{a}}$ & $3920.00^{\mathrm{b}}$ \\
\hline $\begin{array}{l}\text { Feed conversion ratio } \\
\text { (feed:grain) }\end{array}$ & $2.46^{\mathrm{ab}}$ & $2.48^{\mathrm{ab}}$ & $2.50^{\mathrm{a}}$ & $2.45^{\mathrm{b}}$ \\
\hline Dressing percentage & $70.56^{\mathrm{a}}$ & $75.23^{\mathrm{a}}$ & $72.40^{\mathrm{a}}$ & $65.15^{\mathrm{b}}$ \\
\hline Mortality & $0^{\mathrm{a}}$ & $0^{\mathrm{a}}$ & $0^{\mathrm{a}}$ & $4^{\mathrm{a}}$ \\
\hline
\end{tabular}

Means in the column with similar superscripts are not significantly different at $\mathrm{P}<0.05$

Table.2 Manureal value of different litter materials

\begin{tabular}{|l|l|l|l|l|l|}
\hline \multicolumn{2}{|c|}{ Parameters } & \multicolumn{4}{|c|}{ Types of litter } \\
\cline { 3 - 6 } & $\begin{array}{c}\text { Wheat } \\
\text { straw }\end{array}$ & Rice husk & Mustard stalk & Sand \\
\hline $\begin{array}{c}\text { Moisture } \\
\text { content } \\
(\%)\end{array}$ & Week 1 & $8.15^{\mathrm{b}}$ & $11.4^{\mathrm{a}}$ & $7.80^{\mathrm{b}}$ & $2.2^{\mathrm{c}}$ \\
\hline Nitrogen (\%) & $40.4^{\mathrm{b}}$ & $45.3^{\mathrm{a}}$ & $38.7^{\mathrm{b}}$ & $17.4^{\mathrm{c}}$ \\
\hline \multicolumn{2}{|c|}{ Phosphorus (\%) } & $2.20^{\mathrm{b}}$ & $3.40^{\mathrm{a}}$ & $1.80^{\mathrm{c}}$ & $1.53^{\mathrm{d}}$ \\
\hline Potassium (\%) & $0.98^{\mathrm{b}}$ & $1.35^{\mathrm{a}}$ & $0.85^{\mathrm{b}}$ & $0.78^{\mathrm{c}}$ \\
\hline \multicolumn{2}{|c|}{} & $0.25^{\mathrm{b}}$ & $0.32^{\mathrm{a}}$ & $0.23^{\mathrm{b}}$ & $0.18^{\mathrm{c}}$ \\
\hline
\end{tabular}

Means in the column with similar superscripts are not significantly different at $\mathrm{P}<0.05$

Table.3 Economics of different litter materials

\begin{tabular}{|c|c|c|c|c|}
\hline Types of litter & $\begin{array}{c}\text { Amount } \\
\text { required/fft } \\
(\mathrm{kg})\end{array}$ & $\begin{array}{c}\text { Price/kg } \\
\text { (Rs) }\end{array}$ & $\begin{array}{l}\text { Price/ft }{ }^{2} \\
\text { (Rs) }\end{array}$ & $\begin{array}{c}\text { Price/1000 } \mathrm{ft}^{2} \\
\text { (Rs) }\end{array}$ \\
\hline Wheat straw & 0.7 & 2.4 & 1.68 & 1680 \\
\hline Rice husk & 0.5 & 2.9 & 1.45 & 1450 \\
\hline Mustard stalk & 0.9 & 1.7 & 1.53 & 1530 \\
\hline Sand & 2.9 & 0.6 & 1.74 & 1740 \\
\hline
\end{tabular}




\section{Economics of different litter materials}

Economics of the four different bedding materials was calculated on the basis of market prices at the time of trial. Keeping the standard floor space of one square foot per broiler, prices of different litter materials were calculated. The cost of wheat straw, rice husk, mustard stalk and sand was Rs. 1680, 1450, 1530 and 1740, respectively for rearing 1000 broiler chicks (Table 3). The rice husk had an edge on wheat straw, mustard cake and sand due to its very high moisture absorbing ability, rice husk is also better than wheat straw, mustard cake and sand in respect of availability and economics.

\section{References}

Almeida Paz, I.C.L., García, R.G., Bernardi, R., Näas, I.A., Caldara, F.R., Freitas, L.W., Seno, L.O., Ferreira, V.M.O.S., Pereira, D.F. and Cavichiolo, F. (2010) Selecting appropriate bedding to reduce locomotion problems in broilers. Braz. J. Anim. Sci. 12 (3): $189-195$

Avila, V. S., U. Oliveira, E. A. P. Figueiredo, C. A. F. Costa, V. M. N. Abreu, and P. S. Rosa. 2008. Avaliação de materiais alternativos em substituição à maravalha como cama de aviário. Braz. J. Anim. Sci. 37: 273-277.

Brake, J.D., Fuller, M.J., Boyle, C.R., Link, D.E, Peebles, E.D. and Latour, M.A. (1993). Evaluations of whole chopped kenaf and kenaf core used as a broiler litter material. Poult. Sci. 72: 2079-2083.

Davasgaium, M.M. and Boodoo, A.A. (2000). Use of bagasse as a potential source of litter material for broiler production. Internet address: $\quad$ http://farc.gov.mu/amas97 /html/p18txt.htm.

Grimes, J.L., Carter, T.A., Godwin, J.L. (2006). Use of a litter material made from cotton waste, gypsum, and old newsprint for rearing broiler chickens. Poult. Sci. 85: 563-568.

Gunnarsson, S., Matthews, L.R., Foster, T.M. and Temple, W. (2000). The demand for straw and feathers as litter substrates by laying hens. Appl. Anim. Behavior Sci. 65: 321330.

Hussain, S.A., Zahid, S., Akhtar S. and Saleem, K. (1996). Effect of different types of litter materials on the performance of broilers. Pak. J. Zool. 28: 181-182.

Kassid, I.F.H. and Coleman, T.H. (1990). The effect of using anaphage (D.P.W.) or shavings as litter. Poult. Abstr. 16: 54.

Lien, R.J., Conner, D.E. and Bilgili, S.F. (1992). The use of recycled paper chips as litter material for rearing broiler chickens. Poult. Sci. 71: 81-87.

Mendes, A.S., Paixao, S.J., Restelatto, R., Reffatti, R., Possenti, J.C., de Moura, D.J., Morello G.M.Z. and Carvalho, T.M.R (2011). Effects of initial body weight and litter material on broiler production. Braz. J. Poult. Sci. 13 (3): 165-170.

Monira, K.N., Islam, M. A., Alam, M. J. and Wahid, M.A. (2003). Effect of litter materials on broiler performance and evaluation of manureal value of used litter in late autumn. Asian-Aust. J. Anim. Sci. 16 (4): 555-557.

SAS (2000) Institute. SAS User's guide: Statistics version 9.0.

Shields, S.J, Garner, J.P, Mench, J.A. (2005). Effect of sand and wood-shavings bedding on the behavior of broiler chickens. Poult. Sci. 84: 1816-1824.

Sreehari, S. and Sharma, R.K. (2010). Effect of litter type and stocking density on the performance of broilers. Indian J. Poult. Sci. 45 (1): 105-107.

Steel, R.G.D. and Torrie, J.H. (1981). Principles and procedures of statistics: A biometrical approach. $2^{\text {nd }} E d$. McGraw-Hill, Singapore.

\section{How to cite this article:}

Dhaliwal, A.P.S., Balwinder Singh Dhillon and Brar, J.S. 2018. Evaluation of Different Litter Materials for Broiler Production. Int.J.Curr.Microbiol.App.Sci. 7(12): 1041-1045.

doi: https://doi.org/10.20546/ijcmas.2018.712.130 